\title{
Indonesian Economic Diplomacy on Obtaining Market Access of Wood Products in EU Countries with Forest Law Enforcement, Governance and Trade - Voluntary Partnership Agreement (FLEGT-VPA) (2007-2016)
}

\author{
Komang Audina Permana Putri \\ Program Studi Ilmu Hubungan Internasional, Universitas Katolik Parahyangan - Indonesia \\ Email: aukomang@gmail.com \\ Submitted: 13 August 2020 | Accepted: 29 December 2020
}

\begin{abstract}
Forestry has played an important role in Indonesia's economic development, particularly in export activities. Major importer countries of Indonesian wood products comprise to several European Union countries. However, Indonesia export on wood product activities has significant challenge on the legality of products due to the illegal logging in Indonesia. Meanwhile, EU has committed to regulate the issue through Forest Law Enforcement Government and Trade (FLEGT) and force to reject Indonesian wood products in 2002. Thus, the purpose of this article is to analyze Indonesian government economic diplomacy to obtain woods market in EU. This article will use qualitative method with linking data to propositions using economic diplomacy and international cooperation theory. Hence, from 2007 Indonesian government held negotiations with EU to share the view that the cooperation in combating illegal logging shall be carried out with appropriate management measures in accordance with the prevailing laws and regulations in Indonesia as well as EU. This includes Indonesian government to sign Voluntary Partnership Agreement (VPA) with EU and establish Indonesian Timber Legality Verification System. Thus, the cooperation between Indonesian and European Union through FLEGT-VPA will give an idea of how Indonesian government's strategy to obtain woods market in EU.
\end{abstract}

Keywords: EU, Indonesia, FLEGT-VPA, Woods, Trade, Diplomacy

\begin{abstract}
Abstrak
Kehutanan memainkan peran penting dalam pembangunan ekonomi Indonesia khususnya kegiatan ekspor. Negara pengimpor utama produk kayu Indonesia terdiri dari beberapa negara Uni Eropa. Namun, kegiatan ekspor produk kayu Indonesia memiliki tantangan terhadap legalitas produk karena pembalakan liar di Indonesia. Sementara itu, UE telah berkomitmen untuk mengatur masalah tersebut melalui Forest Law Enforcement Government and Trade (FLEGT) dan terpaksa untuk menolak produk kayu Indonesia pada tahun 2002. Tujuan dari artikel ini adalah untuk menganalisis diplomasi ekonomi pemerintah Indonesia untuk mendapatkan pasar kayu di UE. Artikel ini akan menggunakan metode kualitatif dengan menghubungkan data dengan proposisi menggunakan teori diplomasi ekonomi dan kerjasama internasional. Sejak tahun 2007 pemerintah Indonesia melakukan negosiasi dengan UE untuk berbagi pandangan bahwa kerjasama dalam pemberantasan illegal logging harus dilakukan dengan langkah-langkah pengelolaan yang tepat sesuai dengan peraturan perundang-undangan yang berlaku di Indonesia maupun UE. Termasuk pemerintah Indonesia untuk menandatangani Voluntary Partnership Agreement (VPA) dengan UE dan membentuk Sistem Verifikasi Legalitas Kayu Indonesia. Oleh karena itu, kerjasama antara Indonesia dan Uni Eropa melalui FLEGT-VPA akan memberikan gambaran bagaimana strategi pemerintah Indonesia untuk mendapatkan pasar kayu di UE.
\end{abstract}

Kata kunci: UE, Indonesia, FLEGT-VPA, Kayu, Perdagangan, Diplomasi 


\section{INTRODUCTION}

Indonesia has the third largest tropical rainforest in the world, covering $60 \%$ of the country's total area. As a country that is often referred as the lungs of the world, Indonesia has 133.6 million ha of forest from a land area of 181.2 million ha, which makes Indonesia has high potential for wood productions. According to data, from the total forest area in Indonesia, $37 \%$ is used for conservation, $46 \%$ is used for production and export, and the remaining $17 \%$ is for other uses (Indonesia-EU FLEGT Report, 2015).

Forestry has played an important role in Indonesia's economic development. Forestry and related products contribute around 3.5 percent to Indonesia's GDP and contribute to the livelihoods of 15 million people (ITS Global, 2011). The main importing countries for Indonesian wood products come from several countries such as China, Germany, Japan, the European Union (EU), India and the Middle East. Looking through the data of importing countries for Indonesian wood products, EU countries hold about $40 \%$ and this is recorded in the Food and Agriculture Organization (FAO). Hence, it makes the European Union is the largest share of important countries because the EU has a very high market potential for Indonesian wood product (IT'TO Report, 2008).
However, the export activities for Indonesian wood products meet significant challenges due to the legality of forestry and related products. The problem of illegal logging in Indonesia has become a major historical problem in Indonesia surrounding the forestry industry. This is related to the problem that many of the wood products produced by the Indonesian timber industries that used illegal timber (Hadija, 2018).

Therefore, the entry problem for Indonesian products in EU is more likely due to non-tariff issues (Savirra, 2014). In this case, non-tariff barrier of trade is a form of inclusion of certain requirements for wood products that enter a country, such as the legality of raw materials and environmentally friendly products. Especially after Bali Declaration on Forest Law Enforcement Governance in 2001, many countries began to carry out certification and regulatory processes that were able to directly protect exporters and importers of forest products from crimes and damage to forest areas. One of them is the European Union countries (Kunkunrat, 2017).

From that concern, the European Union took serious steps regarding this issue, by building a FLEGT Action Plan in 2003. Then the FLEGT 
Action Plan runs two regulations, namely the EU Timber Regulation and FLEGT-VPA. Along with this issue, there is a decline in exports of Indonesian wood products (See Figure 1) $(\mathrm{FAO}, 2001)$. In this case, in 2002
EU as a buyer refuses to import these wood products due to their high commitment to forest and environmental sustainability

(Kunkunrat, 2017).

Figure 1. Decline in Export Volume of Indonesian Wood Products to All Importing Countries, Including the EU (Measured in Cubic Meters).

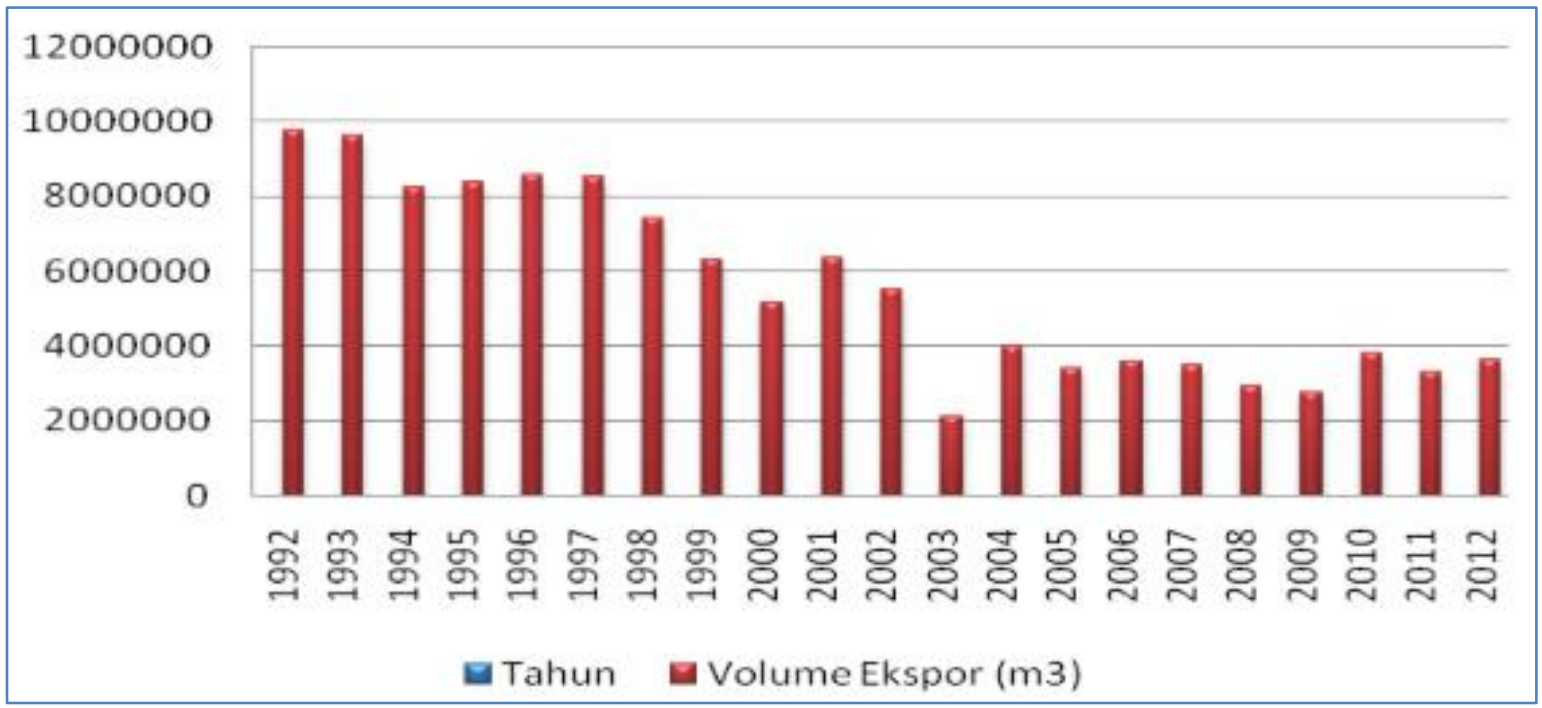

Source: FAO yearbook 1997 and 2001

Various types of wood and forest products from Indonesia are exported annually throughout the world, such as plywood, pulp, paper, furniture and handicrafts (FAO, n.d). The decline in export of Indonesian wood products illustrates the urgency of European countries to meet the qualifications of their imported products with more strict regulation (Savirra, 2014). The diagram above shows that the export value of wood products reached its lowest point in 2003 and continues to fluctuate. One of the reasons for this to happen is because Indonesian timber was gradually being rejected due to illegal logging practices.

In addition, a sharp decline in production has been recorded since 2002, which has correlation in decreasing availability of raw materials for the plywood industry (Hadija, 2018). This was followed by a continuous decline in Indonesia's plywood production as well as its export volume.

Illegal logging has played significant impact for Indonesian wood productions. Some of the 
Indonesian government action in order to tighten the regulation on illegal logging practice also impact on Indonesian export on wood products (Savirra, 2014).

The illegal timber trade is very harmful both for Indonesia's economic, social and environmental perspective. It is estimated that the Government of Indonesia loses 3.7 billion dollars in revenue per year due to logging and illegal timber exports (Hadija; 2018). Meanwhile, according to the WWF Report, Indonesia is one of the top ten countries that have illegal export timber products entering the EU (data can be seen in Figure 2).

Figure 2. Top 10 Illegal Timber Exporting Countries to the EU.

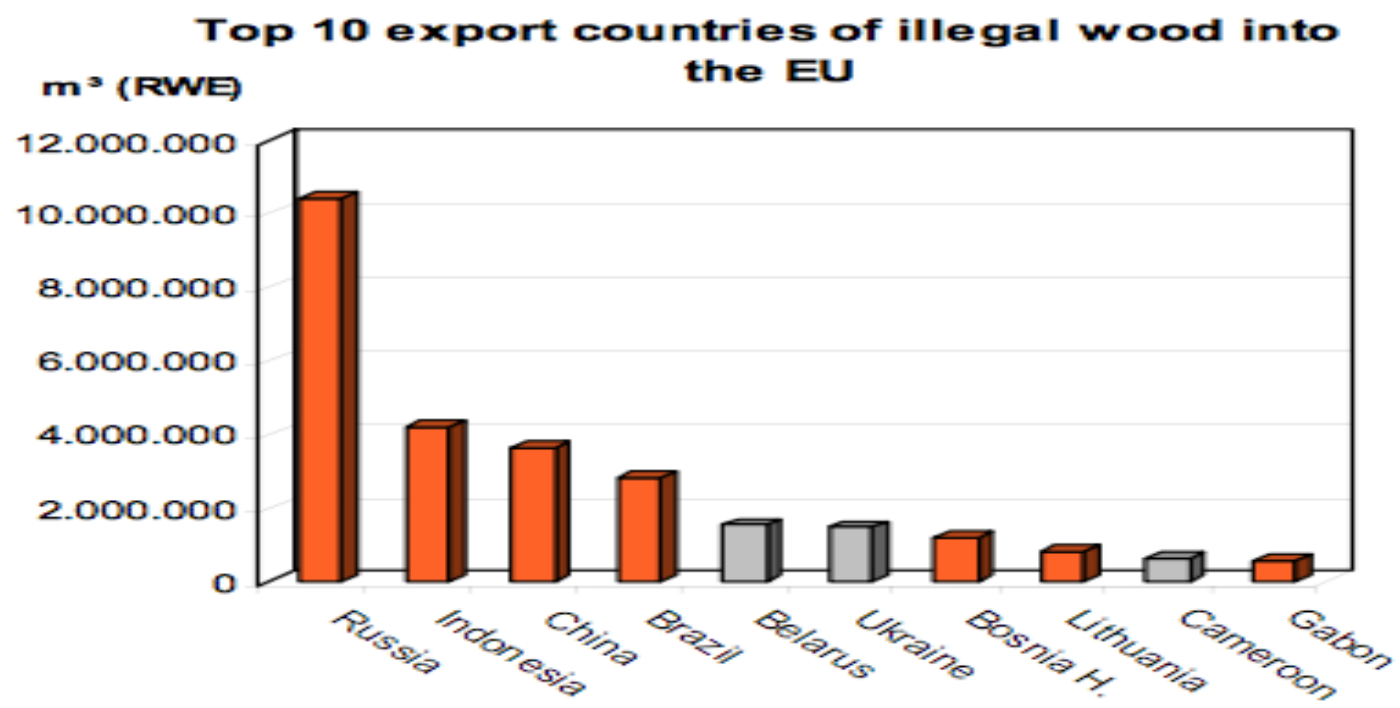

Source: WWF Report. (2008) Illegal Logging and The EU: An Analysis of the EU Export and Import Market of Illegal Wood and Related Products.

Therefore in 2003, the EU established the Forest Law Enforcement Governance and Trade (FLEGT)-Action Plan as the EU standard for managing the certification of imported wood products. This European Union Action Plan was developed not only focusing on legality for imported wood products but also to provide a foundation for sustainability in forest management (EU Commission Of The European Communities, 2003). This has become the factor for Indonesian government urgency to conduct cooperation with EU and reform its policy to adjust the certification. 


\section{METHOD}

The research method in this article uses qualitative research methods. Qualitative concept will be used to observe through theory and other relevant sources. In addition, the author also uses the Library Research method to analyze historical records or existing theories. Observations will examine international relations theory of economic diplomacy and international cooperation.

In addition, this study uses the analytical and descriptive type of research method described by Kothari (2004). According to Kothari, social science scholars usually use this type of research because it is more suitable to describe narratively from collected data. In analytic research, researcher will use the available information and facts, which then analyze and evaluate the material (Kothari; 2004). Meanwhile, the descriptive method quite often uses the term Ex Post Facto, where in this study the correlation method is used to find and measure items or data.

Therefore, the data will be processed as an effort or adjustment to the theory used (linking data to proposition) where research is carried out to analyze the efforts of the

Indonesian government to obtain wood product's market in the European Union. The data collection used by the author includes books, journals, press releases and official government or NGO Report, for example documents from the Indonesian Ministry of Forestry, the Indonesian Ministry of Foreign Affairs, the European Forestry Institute (EFI) and WWF Indonesia. Some of them are available and can be collected from the website in the form of publications such as reports.

\section{THEORY}

\section{Economic Diplomacy Theory}

Economic diplomacy underlines diplomatic activities that are focused on increasing exports, attracting investment and participating in the activities of international economic organizations. Economic diplomacy is considered modern diplomacy. The special activities of modern diplomacy are related to the use of economic problems as objects and tools of struggle and cooperation in international relations (Bayne \& Woolcock, 2007).

Economic diplomacy as well as diplomacy in general, is a component of foreign policy for state's international activities. Especially in economic diplomacy used as a foreign policy that defines economic goals and benefits, which constitute a whole series of activities, forms, methods used to realize foreign policy itself. According to Nicholas Bayne and 
Stephen Woolcock (2007), economic diplomacy can be defined as a series of activities (both methods and international decision-making processes) related to cross-border economic activities (exports, imports, investment, loans, assistance, migration) carried out by the state and not-state actors. The form of economic diplomacy consists of three objectives that can be underlined.

First, the use of political relations and influence to promote and influence trade including international investment, to improve market functioning and to overcome market failures and reduce the costs and risks of cross-border transactions. Moreover, economic diplomacy is included in commercial policy, which can involve the role of nongovernmental organizations (NGOs) and is also considered relevant in this diplomacy (Bayne \& Woolcock, 2007).

The second is the use of economic assets and relationships to prevent the cost of conflict and strengthen mutually beneficial cooperation and politically stable

In order to have better policy management after the external cooperative arrangement, strong teamwork of economic agencies between ministries such as economic, forestry and foreign affairs is a essential for effective action (Rana, 2007). The countries that have relationships, namely to increase economic security (Bayne \& Woolcock, 2007). Economic diplomacy can cover structural policies and bilateral trade agreements, which in this article the author will link to the EU-Indonesia agreement (VPA), which aims to achieve certain patterns in trade) and prevent conflict such as trade distortions. Finally, economic diplomacy also can be used as a way to strengthen an appropriate political climate and international political economy environment to facilitate and include multilateral negotiations and cooperation.

Moreover, Rana (2007) states that one of the typologies of economic diplomacy can be called as innovative if it consists of several divisions in diplomatic strategy activities, such as the first, external economic management, such as joined-up and other cooperative arrangements. The second is policy management such as institutionalized management, strong teamwork. And the last is the important role of non-state actors or harmonization with all stakeholders.

combined their foreign affairs and external trade departments are at an obvious advantage, but those that feature effective joined-up and other cooperative formats also do well. In addition to these institutional arrangements at home country, if the diplomatic network also plugged into 
the process, economic advocacy and negotiations are handled optimally.

Therefore, his research will be underlining the cooperation between political and economic interests of Indonesia and the European Union through those strategies divisions of economic diplomacy. Thus, it can be said that economic diplomacy has a broad scope and advantage in international political practices (Bayne \& Woolcock, 2007).

\section{International Cooperation Theory}

International cooperation is one of the efforts of countries to harmonize common interests and is also a manifestation of the condition of an interdependent society. Broadly speaking, international cooperation can be defined as the view that two or more interests, values and goals meet each other and can produce something or a view or hope from a country that policies decided by other countries can help that country achieve its interests and values (Paulo; 2014). One of the types of contribution in cooperation mechanism such as setting rules or standards contributes for the common interest by changing and coordinating the behaviors among actors. Knowledge as a contribution to global problem-solving processes provides options and identifies solutions that inform changes in rules and standards (Paulo, 2014).

\section{RESULT AND DISCUSSION \\ FLEGT-VPA Cooperation between Indonesia and the EU}

The response of the European Union to address the issue of illegal logging has been stated in the Forest Law Enforcement, Governance and Trade (FLEGT) Action Plan published in 2003 (EEAS; 2011). The points that underline in the FLEGT Action Plan established by the EU cover the following matters, such as to support timber producing countries, to promote trade in legal timber in particular through the negotiation of Voluntary Partnership Agreements (VPA), to promote public procurement policies, support the private sector initiatives, to make safeguards for financing and investment, to use existing legislative instruments or adopt a new legislation to support the plan and to address the problem of conflict timber (EEAS; 2011).

Since the European Union established the FLEGT Action plan as an action to reduce the trade of illegal timber in the EU, which also has affected to Indonesia's export on timber products (Hadija; 2018). This article examines two main strategies of Indonesian government in order to obtain trade market back, which are conducting cooperation and 
negotiation with the EU through FLEGT-VPA.

As one of the strategies in economic diplomacy division is to conduct external economic management such as joint-up or cooperative arrangement, Indonesian government decided to sign FLEGTVPA with EU. However, before the agreement was signed, Indonesia government needed to improve Indonesian Timber Legality Assurance System (TLAS). This action also could not be successful without the involvement from non-state actors in order to exchange information with Indonesian government.

Moreover, according to Rana (2007), the regulatory framework is squarely the responsibility of governments assisted by business chambers, think-tanks and scholars, which aim to create the conditions advance for trade. Moreover, in order to have innovative strategy in economic diplomacy, the home economic agencies and the diplomatic network have to proactively identify the priority areas, negotiate the required agreements, and also keeping in view the mutuality of interests.

In this case, the cooperation between Indonesia and the EU through FLEGT-VPA agreement will demand Indonesian government or agencies assisted by other non-state actors. The FLEGT-VPA agreement basically is a bilateral agreement between the European Union (EU) and timber exporting countries, which aimed to improve forest sector governance and ensuring that timber and wood products imported into the $\mathrm{EU}$ are produced in accordance with the legislation of partner countries. Indonesia

On 30 September 2013, representatives from the Government of Indonesia and the European Union (EU) marked their mutual commitment to ensuring that timber entering the EU is produced legally. They signed a Voluntary Partnership Agreement (VPA) at a ceremony in Brussels (EU-FLEGT Annual Report; 2014). The agreement stated that Indonesia voluntarily participates in cooperation to participate in efforts to stop actions that endanger forests, such as uncontrolled illegal logging (EEAS; 2011). This agreement brought to the fact that Indonesia is the first Asian country to sign a FLEGT-VPA with the EU, and is by far the largest timber exporting country to sign FLEGT-VPA (Hadija; 2018).

With the cooperation between Indonesia and the EU through VPA agreement, Indonesian government needs to ratify it by establishing the SVLK (Timber Legality Verification System). SVLK is a standard system 
for legality of Indonesian wood products that was built and developed through the prevailing multistakeholder approach. The SVLK was then stipulated by Minister of Forestry Regulation No.P38 / 2009 (most recently with the Minister of Environment and Forestry Regulation No. P30 / 2016) regarding the performance assessment of sustainable production forest management and verification of timber legality to permit holders, and management rights (Jaringan Pemantau Independen Kehutanan; 2016).

SVLK itself is mandatory for all business actors to utilize timber forest products from upstream (forest) to downstream (industry and traders). Thus, they need to register their products through the SVLK system and obtain certification according to established standards Jaringan Pemantau Independen Kehutanan; 2016).

In addition, the VPA of timber legality assurance system has five important components, which are, first is a definition of legality. The legality definition clearly states those aspects of Indonesian law where the timber legality assurance system will systematically seek evidence of compliance. Indonesia has different legality definitions for different types of forest uses of rights and permits.
Second is a supply chain control. The purpose of supply chain control is to ensure that unverified products do not enter the supply chain. Third is a verification of compliance: This means checking that all requirements of the VPA legality definition and supply chain controls are met to ensure that the wood product is legal. In Indonesia, 27 independent private companies named Conformity Assessment Bodies verify compliance. It operates under international standardization rules and requires accreditation by an independent Indonesian National Accreditation Committee. Overall oversight remains the responsibility of the government.

Forth is a FLEGT licensing. FLEGT licensing authorities issue FLEGT licenses for shipments of timber products, provided the verification system has proof that the shipment is legally compliant. Indonesia has 25 registered FLEGT licensing authorities (20 active), and the FLEGT licensing scheme began operating on 15 November 2016.

And the last is an independent audit. The purpose of an independent audit is to check regularly that all aspects of the legality assurance system are working properly. The VPA annex provides the auditor's terms of reference. In the Indonesian VPA, the independent audit function is called 'periodic evaluation'. The audit must be 
conducted for no more than 12 months. The auditors will produce reports for the Joint Implementing Committee and public reports. Auditors must comply with international standardization audit rules (EEAS; 2011).

In addition, VPA establishes what is known as the Joint Implementation Committee (JIC) to facilitate monitoring and implementation of the Agreement. Indonesia and the EU will elect their respective representatives to sit on this committee. JIC will facilitate regular dialogue and information exchange between the parties; this committee will publish an annual report, detailing activities, progress and related statistics; and this committee will also assign the necessary monitoring and evaluation activities.

JIC will also be responsible for analyzing various impacts of this Agreement, including impacts on local communities and indigenous and tribal peoples. JIC will be represent not only from Indonesian government however civil society. Thus, it is hoped that civil society representatives will become part of the Joint Implementation Committee (JIC) to contribute a balance and transparent implementation process during the implementation of the Agreement (EEAS; 2011).
In addition, the products included in the agreement cover all major exports wood-based products exceeding the five core categories listed in the 2005 EU-FLEGT Regulation namely logs, sawn timber, veneer, plywood and railroad bearings (EEAS; 2011). The agreement includes several wood products such as wood chips, wood products that have been printed, and wood-based panels, or pulp and paper, paper products and wood furniture. Since Indonesian law prohibits the export of logs and rough sawn timber and rail hardwoods with certain dimensions, these types are not included in FLEGT licensing. The VPA stipulates that once FLEGT licensing has begun, the EU will deny entry to any Indonesian timber products covered by the VPA that arrive in the EU without a valid FLEGT license (EU-FLEGT Facility Support; 2014).

Among the $28 \mathrm{EU}$ member states (as in 2007), the main markets for Indonesian products in the European Union are Germany, England, the Netherlands, Belgium, France, Spain and Italy. Meanwhile, Indonesian wood products are exported from all major ports but particularly from Surabaya, Semarang and Jakarta on Java; from Medan and Jambi in Sumatra; from Pontianak, Banjarmasin and Samarinda in Kalimantan; from Makassar in Sulawesi and from smaller 
ports around Papua and West Papua (EEAS; 2011). After achieving the FLEGT-license, Indonesia is expected and obliged to export processed wood products to the European Union using a FLEGT-license. Thus, these main markets can receive back wood products and their derivatives with FLEGT licenses.

However, before Indonesia finally could issue a FLEGT-License on 15 November 2016, various evaluations and revisions to the application of SVLK have been carried out to prepare the system for readiness (BPPP Kementerian Perdagangan; 2017). This is another effort of Indonesian government to conduct negotiations that will lead to better policy management such as institutionalized management with strong teamwork.

The economic diplomacy act conducted through several negotiations with the involvement of non-state actors. Stakeholders not only Indonesian government agencies, however civil society groups, the Forest and Timber Industry Association have been in direct contact with and contributed to negotiations with the EU through various forms and spaces of dialogues.

Thus, multi-stakeholder participation is critical to the success and credibility of the Indonesia-EU
VPA. The high level of stakeholder engagement during the development of the SVLK and during the VPA negotiations also has continued in the implementation phase of the VPA.

There is strong support for VPA implementation and continuous improvement of the SVLK among civil society, government institutions and the private sector. This includes Ministry Of Environment And Forestry Republic of Indonesia, Ministry of Foreign Affairs and Ministry of Economic (SILK Dephut Document; n.d).

Indonesia and the EU started VPA negotiations in January 2007 but only after July 2009 the dialogue intensified thereafter completion of the Indonesian timber legality assurance system (TLAS) (Kunkunrat, 2017). Moreover, the diplomatic approach carried out by representatives of the Indonesian government and the European Union was recorded that from March 2007 to April 2011.

There were three Senior Officials Meetings (Senior Officials Meeting), seven Technical Working Group Meetings (Technical Working Groups), seven Joint Expert Meetings (Joint Expert) and eight Videoconferences to finalize and agree on the VPA text and its attachments (Ministry of Forestry Republic of 
Indonesia; n.d). It also shows that the process of negotiations have to lead better institutional management between three ministries including Indonesia's Ministry of Foreign Affairs, Ministry of economic and Forestry.

The meetings of the Indonesian government and a delegation from the European Union did not only discuss how Indonesian certification could be integrated with European Union policies, but there was a discussion on supervision, related institutions supported by civil society, for instance the establishment of JIC.

Moreover, during discussions between various Indonesian stakeholder groups and during negotiations between Indonesia and the $\mathrm{EU}$, a number of issues have been identified that require additional technical guidance by Indonesia with more involvement from civil society. Additional activities that need to be carried out as part of VPA implementation are: 1) developing technical guidelines for independent monitoring by civil society; 2) developing technical guidelines regarding the legality of timber import goods to Indonesia; 3) developing guidelines for the availability of forestrelated information in the public domain; 4) developing a procedure for Full Evaluation, and 5) establishing a license information unit in connection with the export license procedure (EEAS; 2011).

The meeting held by the Indonesian government and the EU delegation provided an overview of significant cooperation and result of Indonesia's first FLEGT-license certification in 2016. Of course this does not only prove the results of economic diplomacy for the interests of one party, in this case Indonesia, but also for the European Union commitments to reduce the use and distribution of timber products from illegal logging.

\section{CONCLUSION}

The author concludes that Indonesian government's economic diplomacy to obtain market of wood products in the European Union is divided into two steps, namely cooperation and negotiations in order to reform policies so that could be in line with EU certification standards. It namely formed SVLK certification. SVLK itself can improve the previous certification system, which lack in transparency for the audit process, land conflict issues, and corrupt practices in the licensing process.

In addition, not only adjusting to FLEGT regulations, Indonesia also needs to sign a Voluntary Partnership Agreement (VPA) as a commitment by the Indonesian government to follow 
the FLEGT Action Plan. The agreement basically committed for Indonesia and EU to carry out further negotiations through the Joint Implementation Committee Meeting to monitor the progress of the system and Indonesia's policy reforms.

However, diplomatic approaches and negotiations already been carried out by representatives of the Indonesian government and the European Union recorded since March 2007 to April 2011. There were three Senior Officials Meetings (Senior Officials Meeting), seven Technical Working Group Meetings (Technical Working Groups), seven Joint Expert Meetings (Joint Expert) and eight Videoconferences to finalize and agree on the VPA text and its attachments.

Furthermore, the meeting of the Indonesian government with delegations from the European Union did not only discuss how Indonesian certification could be integrated with European Union policies, but there was a discussion on supervision, related institutions supported by civil society. Therefore, those are two main economic diplomacy acts that held by Indonesian government.

Those efforts included in such as institutionalized management with strong teamwork. Throughout the processes, there are strong cooperation between Indonesia's
Ministry of Foreign Affairs, Ministry of Economic and Forestry. Moreover, through several negotiations conducted by Indonesian government with EU could not be successful without the harmonization from the non-state actors' involvement, such as civil society groups and the Forest and Timber Industry Association. In fact, the roles of Indonesia civil society have been significant during VPA negotiations and the SVLK preparation. Also with the Joint Implementation Committee that involves civil society on VPA implementation indicates the important role of the Indonesian civil society representative.

Thus, conducting several negotiations and eventually signed VPA have led to better policy management for both parties, EU and Indonesia. As a result, Indonesian government finally established SVLK certification, which then be used into the EU market as a FLEGT licensed. Therefore, the process will not go through a long legality certification. It means that EU importers do not need to carry out further processes, namely as "due diligence" on FLEGT-licensed timber from Indonesia. Thus, it will make easier for business actors to export products to the European Union.

Looking through the indicators of innovative economic diplomacy, 
which includes external cooperation, policy management and harmonization of multi-stakeholder, the efforts of Indonesian government shows the right way in order to redesign Indonesia wood production as a real legal framework with new certification scheme and also to prove Indonesia's commitment not only to maintaining timber exports but to overcome illegal logging practices in Indonesia.

Even though, there is a motive for Indonesia's economic interest in participating in this cooperation scheme, namely is to increase the export value of Indonesian forest products to the European Union, however those strategies also show the seriousness of global problems that need to be faced. Both Indonesia and EU are concern about the condition of forests that are continuously being damaged by illegal logging practices.

However, this research still shows some limitation on data collections for some details interactions among Ministries that involve in FLEGT-VPA process or negotiations. However, the author hopes that this article will show an idea of how Indonesian government economic diplomacy to obtain woods market in EU and might useful for further research regarding to this topic.

\section{REFERENCES}

Bayne, N., \& Woolcock, S (2007) The New Economic Diplomacy: Decision Making and Negotiation in International Economic Relations $2^{\text {nd }}$ edition. Aldershot: Ashgate.

Berridge, G.R. (2005) Diplomacy: Theory and Practice $3^{\text {rd }}$ edition. Houndmills: Palgrave.

BPPP Report; Ministry of Trade Republic of Indonesia. (2017) Indonesia; Peraib Flegt Pertama di Dunia. Retrieved from http://jpik.or.id/wpcontent/uploads/2016/11/JPIKNewsletter_EdisiV_AgustusNovember.pdf (Accessed: 28 February 2019).

EU Commission Of The European Communities. (2003) FLEGT Document. Retrieved from http://www.euflegt.efi.int/documents /10180/23398/FLEGT+Action+Pla n/3c0cfca1-1503-458a-9d051717bf226e23 (Accessed: 28 February 2018).

EU-FLEGT Facility Support. (2014) Indonesia-EU VPA; Annual Report 2014. Retrieved from https://www.euflegt.efi.int/document s/10180/211477/VPA+Annual+Rep ort+Indonesia-EU+20142015.pdf/09c63a6a-377f-4b4e-99e1cb3808a9a52c (Accessed: 28 February 2018).

European Commision. (n.d). Indonesia - EU; Indonesia and the European Union signed a historic trade agreement timber from legal sources. Retrived from http://ec.europa.eu/environment/for ests/flegt.html (Accessed: 22 February 2015).

European External Action Service (EEAS) Report. (2011) Kesepakatan Kemitraan Sukarela FLEGT antara Indonesia dan Uni Eropa. EEASE Report: Informasi Ringkas. Retrieved from https://eeas.europa.eu/archives/dele 
gations/indonesia/documents/eu_ind onesia/euidn_vpa_201105note_id.pdf (Accessed: 28 February 2018).

FAO (Food, Agriculture Organization). (2001) Yearbook 1997 and 2001.

Retrieved from https://agris.fao.org/agrissearch/search.do? recordID $=$ XF20044 05323 (Accessed: 20 Mei 2018).

Frankel, J. (2008) 'Environmental Effects of International Trade'. Harvard University Working Paper. Retrieved from https://sites.hks.harvard.edu/fs/jfran kel/Swenvirinlaga31 proofs.pdf (Accessed: 20 June 2018).

Hadija. 2018. Dampak Implementasi Kebijakan Uni Eropa "Forest Law Enforcement Governance And Trade (Flegt)" terbadap Perdagangan Kayu Ilegal Di Indonesia. Skripsi Hubungan Internasional Universitas Hasanuddin.

ITS GLobal. (2011) The Economic Contribution of Indonesia's Forest-Based Industries. ITS Global Report. Retrieved form https://static1.squarespace.com/static /562c7435e4b01a45f69f18f9/t/5725d 87707eaa04b68665481/146209804549 $5 /$ The + Economic + Contribution + of + Indonesia's + Forest-

Based+Industries+-

+ Report+Annex+\%282011\%29.pdf

(Accessed: 20 June 2018).

ITTO Technical Report no. 8. (2008) Informasi pasar: standard produk. kayu,persyaratan mutu dan peraturan impor di negara-negara tujuan ekspor produk kayu Indonesia. International Tropical Timber Organization Report. Retrieved from http://www.itto.int/files/itto_project _db_input/2537/Technical/TR-8.pdf (Accessed: 20 June 2018).

Jaringan Pemantau Independen Kehutanan (JPIK). (2016) Newsletter JPIK. Retrieved from http://jpik.or.id/wpcontent/uploads/2016/11/JPIKNewsletter_EdisiV_Agustus-
November.pdf (Accessed: 20 June 2018).

Kothari, R. C. (2004) Research Methodology; Methods and Techniques. Second Revised Edition. New age international publisher; New Delhi.

Kunkunrat, Hariyadi Riska P. (2017) "Kerja Sama FLEGT-VPA (Forest Law Enforcement Government and TradeVoluntary Partnership Agreement) Indonesia-Uni Eropa dalam Peningkatan Ekspor Produk Hasil Hutan Indonesia ke Uni Eropa." Jurnal Transborders Universitas Pasundan, Vol. 1(1), pp. 50-60.

Ministry of Environment And Forestry Republic of Indonesia (SILK.DEPHUT). (n.d) The Anthology of RI-EU FLEGT VPA Documents on JEM, TWG, SOM, and post VPA Ratification (JIC \& JWG). Retrieved from

http://silk.dephut.go.id/app/Upload /repos/20190625/38a6d3a83f089d71 fcdd1d13a065311c.pdf (Accessed: 20 June 2018).

Ministry of Environment And Forestry Republic of Indonesia. (2015) Laporan Kemenlu 2014-2015. Annual Report 2014-2015.

Ministry of Foreign Affairs of Republic of Indonesia. (2014) "Dilpomacy book 2014”. Majalah Diplomasi. Jakarta: Directorate General of Information and Public Diplomacy.

P.M Erza Killian. (2012) "Paradigma dan Problematika Diplomasi Ekonomi Indonesia." Global \& Stategies Journal, Vol 6, No. 2, pp. 170-183. Retrieved from http:/ /journal.unair.ac.id/downloadfullpapers-jgsd095c88cd12full.pdf (Accessed: 20 June 2018).

Paulo, S. (2014) 'International Cooperation Development; A Conceptual Overview.' Discussion Paper. German: DIE. Retrieved from 
https://www.diegdi.de/uploads/media/DP_13.2014.. pdf (Accessed: 20 June 2018).

Rana, Kishan S. (2007) Economic Diplomacy: The Experience of Developing Countries, in The New Economic Diplomacy: Decision Making and Negotiation in International Economic Relations (ed). Nicholas Bayne and Stephen
Woolcock. London: Ashgate, pp. 200250.

Savirra, Clarrisa Diva C. (2014) "Supply \& Demand Driven Factor Analyst Against Indonesia's Inclination in Realizing the 2007-2011 FLEGTVPA Cooperation Agreement." Journal of International Relations Analysis, Airlangga University, Vol 3 (3), pp. 935 - 955 . 